\title{
Tissue Engineering in Regenerative Dental Therapy
}

\author{
Hiral Jhaveri-Desai, BDS, MDS ${ }^{1 *}$; Shaleen Khetarpal, BDS, MDS ${ }^{2}$ \\ ${ }^{1}$ Private Practice, Sydney, NSW, Australia \\ ${ }^{2}$ Department of Periodontics \& Oral Implantology, Government College of Dentistry, \\ Indore, India
}

Submitted March 2011. Accepted for publication August 2011

\begin{abstract}
Tissue engineering is amongst the latest exciting technologies having impacted the field of dentistry. Initially considered as a futuristic approach, tissue engineering is now being successfully applied in regenerative surgery. This article reviews the important determinants of tissue engineering and how they contribute to the improvement of wound healing and surgical outcomes in the oral region. Furthermore, we shall address the clinical applications of engineering involving oral and maxillofacial surgical and periodontal procedures along with other concepts that are still in experimental phase of development. This knowledge will aid the surgical and engineering researchers to comprehend the collaboration between these fields leading to extounding dental applications and to ever-continuing man-made miracles in the field of human science.
\end{abstract}

Keywords: tissue engineering, oral surgery, dentistry, wound healing

\section{INTRODUCTION}

The human body has a remarkable capacity for regeneration. With understanding and advancements in the surgical field, techniques of restoring structure and function have become integral to the advancement of human therapy. The goal of surgical therapy is to eliminate the diseased/affected tissue and regenerate or replace the lost tissue structure. Tissue transplantation has long been performed to this effect to restore essential functions. There is but one constraint. The number of patients requiring transplants far exceeds the available supply of donors. This has led to new solutions to provide the missing tissues. It is in this context that the field of tissue engineering has emerged.

Tissue engineering is a multidisciplinary field employing knowledge of tissue and molecular biology for the growth and development of new tissues, knowledge of biomaterials and engineering principles for engineering functional tissues, and knowledge of surgery and medicine in order to translate the scientific component to

${ }^{*}$ Corresponding Author: Hiral Jhaveri-Desai, 17/36-44 Fontenoy Road, Macquarie Park, NSW 2113 (Australia); Phone: +61-433252941; Email: heer2183@gmail.com. Other author: drshaleenk@gmail.com 
clinical application. This exciting field holds the promise of creating an almost unlimited supply of "off the shelf" tissue replacement alternatives and is likely to revolutionize the ways we improve the health and quality of life for millions of people worldwide by restoring, maintaining, or enhancing tissue and organ functions.

\subsection{Tissue Engineering Approaches}

There are three main approaches taken in the field of tissue engineering: conduction, induction by bioactive factors, and cell transplantation [1,2]. The basic idea behind using tissue engineering for reconstructing any tissue defect is to provide the defective tissue with ample number of viable and responsive cells. These viable cells can either generate or induce the surrounding resident cells to regenerate the lost cells and tissue structure. To achieve this type of regeneration, the viable cells need to be transferred to the defect that needs to be protected from premature collapse of overlying tissues under the natural biological forces that the tissue is subjected to during the healing process. Hence, there is the need for an appropriate extracellular matrix or carrier construct which would serve these purposes by acting as a scaffold to hold the cells and by providing adequate mechanical resistance. In addition to the cells and scaffold, appropriate levels and sequences of biological signaling molecules are required to regulate various aspects of cell growth and development, provide the necessary gene expression and instruct the cells to form the desired tissue type and aid in various aspects of the healing process. Thus, the cells, scaffolds and necessary environmental cues in the presence of vascularization would regenerate the lost tissue (see Fig. 1). Another way of reconstructing the defect would be to form the tissue structure ex vivo before transplanting it in vivo in toto. Whatever the approach, the three components, viz. cells, scaffolds and bioactive molecules, along with an adequate blood supply form the crux of tissue engineering in regenerative applications and could together regenerate many hard and soft tissues.

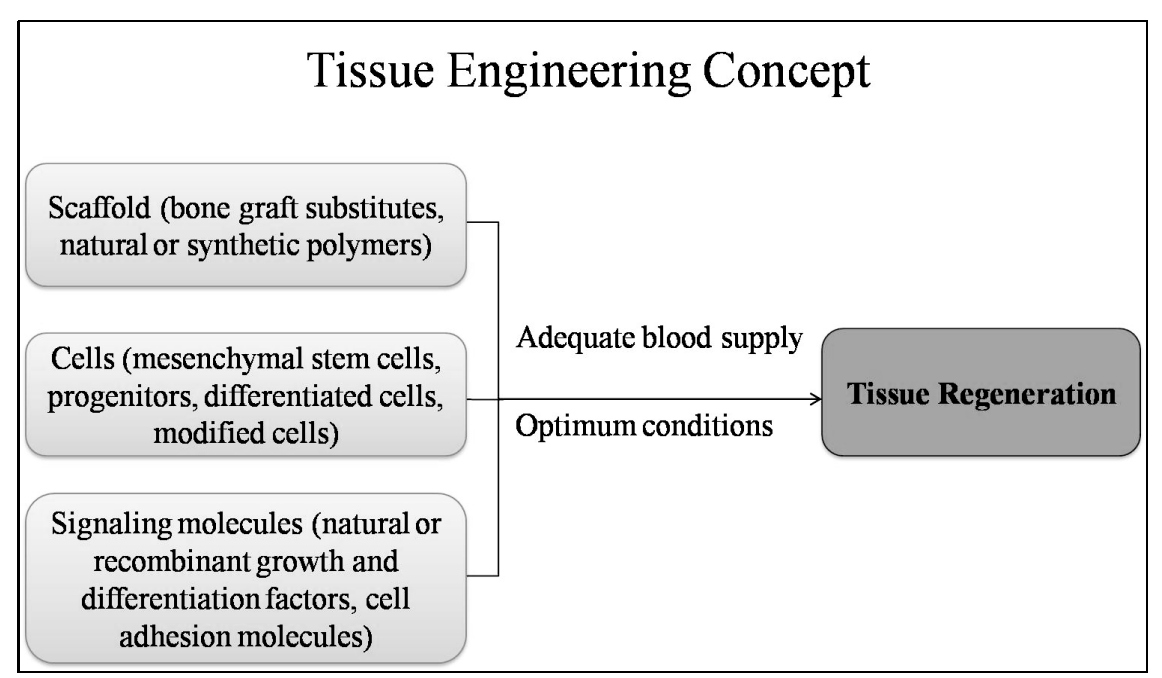

Figure 1. The concept of tissue engineering. 


\subsection{Cells}

One of the main determining components of tissue engineering are the cells, which can be stem cells, progenitors, or differentiated cells such as osteoblasts, fibroblasts, and cementoblasts. They can be autologous, allogeneic, xenogeneic, genetically-altered or phenotypically-altered cells. Stem cell research offers tremendous potentials for addressing those human diseases that have been difficult to treat effectively. However, government regulations and legal and ethical issues involving the use of embryonic stem cells have led researchers to explore postnatal stem cell populations obtained from adult tissues. Although adult stem cells may have a more restricted differentiation potential compared with the totipotent properties of embryonic stem cells, they still fulfill the basic characteristics of stem cells in terms of abilities to self-renew, generate large numbers of progeny and differentiate into multiple mature cell types [3]. These stem cells or differentiated cells can be obtained from the subject via a small tissue biopsy or aspirate, isolated and expanded into large quantities in vitro, and transplanted back into the defect area.

Post-natal stem cells have been isolated from various tissues including bone marrow, neural tissue, skin, and retina [4-7]. The major drawback of using bone marrow is the extremely low yield of mesenchymal stem cells (MSCs), ranging from $0.001 \%$ to $0.01 \%$. This poses the limitation of availability, due to the fact that harvesting large volume of human bone marrow is relatively difficult [8]. In the oral cavity, stem cells can be derived from dental pulp [9, 10], periodontal ligament [11-13], exfoliated deciduous teeth [14], and gingiva [15-17]. Dental pulp stem cells have been demonstrated to be clonogenic, rapidly proliferative and able to differentiate into various cell lineages (neurogenic, osteogenic, dentinogenic, and myogenic) [9, 10]. Recently, a separate entity of stem cells, with a high regenerative potential for the pulp/dentin organ and the periodontal ligament (PDL), was isolated from the apical dental papilla (SCAP) $[18,19]$. The apical papilla is different from the pulp in terms of containing less cellular and vascular components than the pulp. Also, the cells in the apical papilla proliferate 2- to 3 -fold faster than those in the pulp in organ cultures.

Periodontal ligament has been explored as a source of stem cells. Experiments have demonstrated that PDL stem cells (PDLSCs) have the potential to generate cementum and PDL-like tissues in vivo [11]. Studies have also shown that viable PDLSCs can be retrieved from frozen PDL tissues [12], increasing the practical potential for these SCs to be used clinically [13]. Human gingiva-derived MSCs can also be a promising alternative to bone marrow-derived MSCs [15-17]. Human gingiva is a tissue that is not only easily accessible from the oral cavity but can often be obtained as a discarded biological sample. Gingival MSCs are easy to isolate, are uniformly homogenous, proliferate faster than bone marrow MSCs, display stable phenotype, maintain normal karyotype and telomerase activity in long-term cultures, and are not tumorigenic [15]. Thus, a large quantity of functionally competent clinical grade MSCs can be generated in a short duration from oral tissues, with advantageous ready availability and easy accessibility. 


\subsection{Scaffolds}

Scaffolds or matrices are specific materials that deliver the cells or signaling molecules to the appropriate anatomic site and provide mechanical support to the forming tissue [20]. The physical and chemical characteristics of a scaffold play a significant role in cell proliferation and tissue in-growth. The exclusive properties of the numerous cellbarrier membranes have been more thoroughly discussed in other reviews [21, 22] and will not be addressed here. Cell-seeding scaffolds are either natural, synthetic, resorbable or non-resorbable (see Table 1). They can be bone graft materials (allografts, xenografts or alloplasts), polymers (natural polymers such as collagen, hyaluronan, skin extracts or synthetic polymers such as polylactic/poly glycolic acid or their copolymer), or a combination of both. Most tissue engineering efforts use biomaterials already approved by the Food and Drug Administration (FDA) as scaffolds.

Scaffolds used for tissue engineering should not only be bioresorbable but also with a suitable affinity for the adsorption of appropriate growth/differentiation factors as well as integrins, cell receptors and other instructive molecules normally found in regenerating tissues $[23,24]$. They should be porous enough to allow blood vessel penetration and facilitate better biofactor delivery without compromising the mechanical function. Among the natural polymers, collagen is regarded as one of the most useful biomaterials owing to its excellent biocompatibility and safety associated with its biological characteristics, such as biodegradability and weak antigenicity. Collagen can induce proliferation and differentiation of cells through direct binding interactions and by serving as a reservoir for growth factors and signaling molecules [25]. Synthetic polymers have also been extensively used in tissue engineering [26]. They can be fabricated to degrade over long or short periods of time, depending on the clinical need. They can also be easily manufactured into preformed sizes and shapes, as dictated by the site of the defect and its anatomy. However, these materials are hydrophobic and are processed under quite stringent (biologically adverse) conditions, usually making factor incorporation and attachment or entrapment of cells difficult. Recently, a biodegradable copolymer of L-lactic acid [D-lactic acid, glycolic acid and trimethylene carbonate (Inion Ltd., Tampere, Finland)] was developed which offers good potential as cell-delivery device, with a possible advantage to allow cell attachment more readily than other inert materials [22]. Some experimental investigations [27, 28] also used scaffolds coated with various peptides sequences which mimic the extracellular components of bone and selectively permit cell binding, osteoblastic phenotypic expression and differentiation, thereby allowing bone regeneration [28].

\subsection{Signaling/Bioactive Molecules}

Signaling molecules aid in wound healing and tissue regeneration by providing important cues and signals to the cells to result in optimum growth, differentiation, cell adhesion, or gene expression [21, 29]. They are broadly grouped into the overlapping categories of mitogens (that stimulate cell division), growth factors (originally identified by their proliferation-inducing effects, but have multiple functions) and morphogens (that control generation of tissue form). Precise control over the signaling of these factors 
Table 1. Commercially available scaffold materials.

\begin{tabular}{|c|c|}
\hline Scaffold Materials & Commercial Name \\
\hline \multicolumn{2}{|l|}{ Natural Polymer } \\
\hline Collagen-based & Collaplug $($, Collacote $\AA$, Gelfoam $\AA$ \\
\hline Fibrin-based & Bioseed $^{\mathrm{TM}}$ \\
\hline Hyaluronic acid-based & Hyaff-11® \\
\hline Chondroitin-based & Integra ${ }^{\circledR}$ \\
\hline Fibroblast-populated skin substitutes & $\begin{array}{l}\text { Dermagraft } \mathrm{t}^{\mathrm{TM}}, \text { Apligraf }^{\mathrm{TM}}, \text { Orcel }^{\mathrm{TM}} \text {, } \\
\text { Hyalograf } 3 \mathrm{D}^{\mathrm{TM}} \text { Polvactive }\end{array}$ \\
\hline Acellular skin substitutes & AlloDerm $\Re$ \\
\hline Synthetic Polymer & \\
\hline $\begin{array}{l}\text { Polyamide-based (Nylon) } \\
\text { Polylactic acid-based }\end{array}$ & TransCyte ${ }^{\mathrm{TM}}$ \\
\hline Polyglycolic acid-based & \\
\hline Poly(lactide-copolyglycolide)-based & \\
\hline \multicolumn{2}{|l|}{ Allografts } \\
\hline Demineralized freeze-dried bone allograft & Available from tissue banks \\
\hline Freeze-dried bone allograft & Available from tissue banks \\
\hline Xenografts & \\
\hline Anorganic bovine bone & Bio-Oss ${ }^{\circledR}$, PepGen P-15® \\
\hline \multicolumn{2}{|l|}{ Alloplasts } \\
\hline Hydroxyapatite & OsteoGraf $₫$, Periograf $®$ \\
\hline$\beta$-Tricalcium phosphate & $\begin{array}{l}\text { OsteoGen }{ }^{\circledR} \text {, Cerasorb } \AA \text {, } \\
\text { SynthoGraft" }{ }^{\mathrm{TM}}, \mathrm{GEM} 21 \mathrm{~S}\end{array}$ \\
\hline Bioactive glass & PerioGlas ${ }^{\circledR}$, BioGran ${ }^{\circledR}$ \\
\hline Hard tissue replacement polymer & \\
\hline \multicolumn{2}{|l|}{ Alloplasts+Polymers } \\
\hline Hydroxyapatite + Bovine collagen & Healos ${ }^{\circledR}$ \\
\hline Hydroxyapatite $+\beta$-Tricalcium phosphate + Bovine collagen & Collagraft $\circledast$ \\
\hline Hydroxyapatite $+\beta$-Tricalcium phosphate+Fibrin & $\operatorname{Tricos}{ }^{\circledR}$ \\
\hline
\end{tabular}


in a local area may potentially allow control over a regenerative process. Currently, a variety of biofactors have been identified, with specific functions that can be used as part of stem cell and tissue engineering therapies. They have been extensively investigated in oral and maxillofacial tissue engineering applications and include recombinant growth and differentiation factors like platelet-derived growth factor-BB (rhPDGF-BB, that regulates growth, division and angiogenesis) [30-35], recombinant human basic fibroblast growth factor (rh-bFGF, potent mitogen for mesenchymal cells and angiogenic factor) [36], autologous preparations of platelet-rich plasma (PRP) [37-39] or plateletrich fibrin (PRF) which are rich in a variety of growth factors like PDGF, transforming growth factor (TGF- $\beta$, potent mediator of inflammation, cell proliferation, differentiation and able to stimulate bone morphogenetic protein (BMP) expression) [40], vascular endothelial growth factor (VEGF, that stimulates neoangiogenesis) [41], basic fibroblast growth factor (bFGF-2), insulin-like growth factor (IGF, that regulates bone formation) [42], epidermal growth factor (EGF, that regulates cell growth, proliferation and differentiation), recombinant human bone morphogenetic proteins (BMPs, potent molecules for bone and cartilage induction) [43-54], enamel matrix derivatives (EMD, that stimulates cell growth, differentiation and angiogenesis) [55-59], and various cell adhesion molecules. A summary of the common biologic mediators used in tissue engineering is provided in Table 2.

Variations in the regenerativehealing response are caused by individual healing capability and surgical techniques. Whereas it is not possible to clinically control individual healing capability, more sophisticated surgical techniques and procedures can be developed which can ensure more predictable outcomes. In the past, crude preparations of biofactors were applied to various cells in culture and their effect was studied. But now with the development of recombinant biotechnology, the quantity and quality of biofactor can be regulated. The advantage of using recombinant growth factors is the consistency in their regenerative capacity as demonstrated by various studies [32-35]. Although many studies attributed improved healing to these growth factors, it is questionable whether the concentrations used were adequate to elicit clinically measurable results. It has also been argued that, when present, the growth factors contribute to core tissue formation, acting on the in situ host stem/progenitor cells rather than on the seeded cells $[60,61]$.

\subsection{Blood Supply}

The first three prerequisites (sufficient number of cells, appropriate scaffolds and necessary bioactive molecules) for regenerating a tissue can be fulfilled by engineering, while the fourth prerequisite, i.e. adequate vascularity, is dependent on patient factors, such as the size of the defect. When a construct is placed into a defect, it is crucial that the native area has a rich blood supply. The peripheral portions of the construct will be in direct contact with the surrounding vascularized tissues; however, the central portion of the graft will be the farthest from the vascular source. Only a sufficient number of new blood vessels within a short period of time guarantee an optimal survival rate of the implanted cells. The size of the graft is also an important factor as smaller-sized constructs (i.e., smaller defect areas) will shorten the diffusion depth, allowing the seeded cells to be optimally supplied by oxygen and nutrients. 
Table 2. The role of biologic mediators in tissue engineering applications.

\begin{tabular}{|c|c|c|}
\hline $\begin{array}{l}\text { Biologic } \\
\text { Mediator }\end{array}$ & Functions & Application in tissue engineering \\
\hline PDGF & $\begin{array}{l}\text { Potent mitogen for mesenchymal cells } \\
\text { (fibroblasts, endothelial cells, osteoblasts) } \\
\text { and chemoattractant for inflammatory cells. }\end{array}$ & $\begin{array}{l}\text { Regulating growth and division of cells, } \\
\text { neoangiogenesis, bone matrix and } \\
\text { extracellular matrix formation. }\end{array}$ \\
\hline IGF & Cell proliferation, bone matrix formation. & Increasing cell numbers, matrix formation. \\
\hline FGF & Mesenchymal cell mitogenesis, angiogenesis. & $\begin{array}{l}\text { Increasing cell numbers, promoting } \\
\text { vascularity. }\end{array}$ \\
\hline EGF & Cell growth, proliferation and differentiation. & Increasing cell numbers. \\
\hline TGF & $\begin{array}{l}\text { Potent mediator of inflammation, stimulating } \\
\text { expression of BMPs, } \\
\text { proliferation/differentiation of osteoblastic } \\
\text { cells, and extracellular matrix formation. }\end{array}$ & $\begin{array}{l}\text { Promoting wound healing and increasing } \\
\text { cell numbers, matrix formation. }\end{array}$ \\
\hline VEGF & $\begin{array}{l}\text { Migration and proliferation of endothelial } \\
\text { cells, increasing permeability of blood } \\
\text { vessels. }\end{array}$ & $\begin{array}{l}\text { De novo formation of blood vessels, growth } \\
\text { of blood vessels from pre-existing } \\
\text { vasculature. }\end{array}$ \\
\hline BMPs & $\begin{array}{l}\text { Stimulate differentiation of MSCs into } \\
\text { osteoblasts and chondroblasts. }\end{array}$ & Formation of bone, cartilage. \\
\hline EMD & $\begin{array}{l}\text { Stimulate cell growth and differentiation of } \\
\text { mesenchymal cells. }\end{array}$ & $\begin{array}{l}\text { Stimulating growth and differentiation of } \\
\text { cells, angiogenesis; inducing cementum } \\
\text { formation. }\end{array}$ \\
\hline CSF & $\begin{array}{l}\text { Stimulate proliferation and differentiation of } \\
\text { mesenchymal stem cells into specific cell } \\
\text { type. }\end{array}$ & Increasing cell numbers. \\
\hline
\end{tabular}

Lack of sufficient vascular supply, resulting in immediate cell death after implantation, is generally thought to be the main cause of failure of tissue engineered graft [62]. It has been shown that improving vascularization of tissue-engineered constructs can advance in vivo cell performance [63, 64]. Several approaches have been investigated to improve the oxygen and nutrient supply. The most common approach is 
to stimulate vessel growth by adding angiogenetic growth factors or endothelial cells to the tissue engineered construct. This approach allows the development of large boneengineered constructs with a high vascularization capacity [65]. Another way is by creating an engineered construct in a muscular environment (ectopic tissue formation) before transplanting into the defect area. Warnke et al. [66] reported successful repair of an extended mandibular discontinuity defect by growth of a custom bone transplant inside the latissimus dorsi muscle of the patient. Meijer et al. [67] suggest postponing the application of the cultured cells for a few days after applying the scaffold. Their rationale is that immediately after implantation of the scaffold, a hematoma is formed. This would ensure that there are new blood vessels at the defect site, and injecting the cultured cells later would guarantee a sufficient supply of oxygen and nutrients and thus securing the survival of the implanted cells. In addition, cells would be implanted at a time point during the wound healing process that the body would normally recruit stem cells to the defect site.

\section{ENGINEERING OF MINERALIZED TISSUES}

\subsection{Bone}

Bone regeneration is perhaps the most widely investigated application of tissue engineering. In the craniofacial region, restoration of bony defects remains an important challenge. Guided tissue and bone regeneration in periodontal and oral implant therapy, sinus augmentation, distraction osteogenesis, reconstruction of oral and maxillofacial bone defects (resulting from trauma, tumour, infections, biochemical disorders, congenital defects, disease or abnormal skeletal development) are some of the clinical situations in which surgical intervention is required.

Bone grafts can either be autologous, allogeneic, xenogeneic or alloplastic. Autogenous graft material from the iliac crest has long been considered as having the greatest potential for osseous regeneration. A patient's own bone, lacks immunogenicity and provides bone-forming cells, which are directly delivered at the defect site and regenerate bone or induce the surrounding cells to form bone [68, 69]. The major drawbacks of autologous bone are their limited availability, need for additional surgical site and donor site morbidity [68, 70]. Allografts and xenografts overcome these drawbacks. However, disease transmission and immunorejection remain substantial obstacles to their implementation [71, 72]. Besides these, synthetic materials have also been investigated extensively as bone substitutes. While many of these materials serve as scaffolds for new bone, their treatment effect has been inconsistent across studies [73] and they appear to mostly produce bone repair rather than regeneration.

To overcome the drawbacks of the current bone graft materials, bone tissue engineering using mesenchymal stem cells and bioactive molecules has been suggested as a promising technique for reconstructing bone defects. Constructs for bone regeneration have been designed based on tissue-engineering principles and comprise three-dimensional scaffolds that function as a carrier for cells or bioactive molecules or both. In the cell-based constructs, living osteogenic cells are carried on scaffolds to the bony defect site to allow the development of a three-dimensional tissue structure. These seeded cells, with the potential for recruiting or differentiating into bone-forming cells, have led to successful bone formation in the management of periodontal defects $[37,38$, 
74], oral implant therapy [39, 75], sinus augmentations [76-79] and oral and maxillofacial defects $[80,81]$. Some studies have also reported the tissue engineering of mandibular condyle having stratified layers of cartilage and bone as a possibility from a single population of bone-marrow derived MSCs [82-84]. Cell survival is the most important requirement for achieving clinical success in cell-based bone tissue engineering. All factors crucial to cell survival need to be understood and taken care of for more predictable bone regeneration.

In the bioactive molecule-based approach, growth factors and proteins are introduced into the bony defects via medium of scaffolds. A great many bioactive factors have been demonstrated to mediate osteoblast activity during the process of bone remodeling $[29,85,86]$. These factors can influence new bone formation through their effects on bone cell recruitment, proliferation, and differentiation [86]. Successful bone regeneration has been achieved in clinical trials with rhPDGF-BB [30-33], rhIGF1 [42], FGF-2 [36], and TGF- $\beta 1$ [40]. Some of the commercially available tissue engineering systems combining the signaling molecules and the scaffolds are plateletderived growth factor-BB-tricalcium phosphate (GEM21S®; OsteoHealth, Shirley, NY, USA), bone morphogenetic protein-type I collagen sponge (INFUSE®; Medtronic Sonfamore Danek, Memphis, TN, USA) and 15 amino acid sequenced type I collagenanorganic bovine material (PepGen P-15; Dentsply Friadent, Mannheim, Germany). Studies have also explored the potential clinical utility of recombinant human bone morphogenetic protein-2 (Wyeth Research, Cambridge, MA), recombinant human osteogenic protein-1(Stryker Biotech, Hopkinton, MA), recombinant human growth/differentiation factor-5 (Scil Technology, Martinsried, Germany), and recombinant human growth/differentiation factor-7 (Wyeth Research) for alveolar augmentation [43-46], sinus lift procedures [47, 49, 78], implant fixation [50-52], and periodontal regeneration $[53,54]$. Besides these, an alternative inductive approach utilizes enamel matrix derivative (Emdogain ${ }^{\circ}$, Emdogain Plus ${ }^{\circledR}$; Straumann, Basel, Switzerland) harvested from developing porcine teeth and has been shown to induce bony tissue regeneration in periodontal defects [55-57] by stimulating cell growth and differentiation of mesenchymal cells, including osteoblasts [58, 59].

A potential drawback of the bioactive factor-based approach is that high, supraphysiologic concentrations of these factors are needed to achieve the desired osteoinductive result, with possible related side effects and high costs [49, 87]. Furthermore, most of these constructs release the growth factors in abundance shortly after placement but are not controlled-released over time, thus in principle limiting the effectiveness of such an approach. Clinical evaluations of the necessary factors, their optimal dose, rate of delivery, all need to be standardized before they can be applied to routine bone regeneration therapy.

Besides these, gene therapy is another approach that offers significant potential to improve growth factor delivery to bony defects in the tooth-supporting and maxillofacial areas [88]. In engineering bone tissue, plasmid DNA encoding for inductive proteins can be incorporated into scaffolds (i.e., gene-activated matrices) and transferred to a bony defect where the DNA is released locally, and transfects surrounding cells to produce peptides encoded by the plasmid DNA [89]. Delivery of plasmid DNA encoding for BMP-4 or PTH1-34 from collagen sponges was shown to 
induce bone formation in a critical defect model, while only fibrous tissue formed in gaps with collagen sponges alone [90]. Delivery of PDGF by gene transfer stimulates remarkable mitogenesis and proliferation of gingival fibroblasts, periodontal ligament, and cementoblasts, in comparison with continuous PDGF administration in vitro [9193]. Other studies used ex vivo methods to transfer genes encoding bone morphogenetic proteins (BMPs) to cells which are then able to differentiate into bone-forming cells when placed in an osseous defect in vivo [94, 95]. While it is anticipated that in the future, gene-enhanced tissue engineering approaches will afford great potential for both hard and soft tissue regeneration, considerable problems remain at present, thus impeding the routine clinical use of gene transfer. With the continued development of improved methods for gene delivery to cells as well as advances in our knowledge of the molecular basis of tooth formation and periodontal homeostasis, it is reasonable to anticipate that a simple chairside protocol could be developed in the future. Tissue engineering can thus be successfully applied to regenerate bone in defective sites. Many of these approaches are in clinical trial phase and appear to be an attractive alternative to bone replacement grafts.

Despite the progress in bone engineering, there are still some limitations to be considered. The significant stress and strain in craniofacial bones, mostly due to the strong muscles of mastication, are significant challenges to any engineered construct [96]. The maxilla and mandible are subjected to multi-vectorial forces from the masticatory apparatus. Hence, the tissue engineering construct designed for their regeneration requires planned load application for proper trabecular orientation and density [97] along with an equally essential plasticity. Also, to improve the outcomes in classical delivery of growth factors, polymer matrices with relevant modifications for the presentation of growth factors could be good platforms as delivery substrates. Bioactive factors can be chemically immobilized or physically encapsulated into polymer matrices, preventing their denaturation, and their release can be controlled by the degradation rate of the polymer matrices, their diffusion through the polymer construct or external triggers $[98,99]$.

\subsection{Teeth}

The goal of modern restorative dentistry is to functionally and cosmetically restore diseased/lost tooth or tooth structure. Tooth structure lost due to decay or trauma is most often replaced by restorative materials. Although these conventional restorative materials have proven to be highly effective at preserving teeth, they have a limited lifespan and ultimately require replacement. Hence, regeneration of the lost tooth structure, as opposed to repairing/replacing, would have significant benefits. The lack of any enamel forming cells in the enamel of fully developed erupted teeth precludes the potential for cell-based approaches for enamel regeneration. In contrast, the regeneration of dentin is feasible (if the pulp tissue is still vital and not irreversibly inflamed) because dentin is in intimate contact with an underlying highly vascular and innervated pulpal tissue, forming a tightly-regulated "dentin-pulp complex". Thus, theoretically, we could possibly restore the dentine lost by disease or trauma. Recent studies have demonstrated that stem cells, of both dental and non-dental origin, are 
capable of inducing odontogenesis and regenerating dentin [100, 101]. Attempts have also been made to regenerate the pulpal tissue using modern tissue engineering concepts [102-104].

In the tooth replacement options, dental implants are amongst the most advanced alternative for replacing lost or missing teeth. However, factors that interfere with osseointegration can lead to failure of the implants [105]. With advances in stem cell biology and tissue engineering, biological teeth may become an alternative for replacing missing teeth [106]. The idea is to cultivate stem cells with odontogenic induction signals through epithelia-mesenchymal interactions, thereby programming the stem cells to adopt dental lineages and, with the help of scaffold/extracellular matrix, to become part of a tooth. Duailibi et al. seeded cultured tooth germ cells on biodegradable scaffolds which were then implanted to bioengineer tooth tissues [107], while Ohazama et al. generated tooth structures from non-dental mesenchymal cells placed in contact with embryonic oral epithelium and transplanted to an ectopic site [108]. The latter report is pivotal in that it demonstrates that uncommitted mesenchymal stem cells, in association with oral epithelium, can be instructed to mimic developmental events leading to growth of a tooth structure comprised of enamel, dentin, and pulp, with a morphology resembling that of a natural tooth. Although replacement of missing or diseased tooth/tooth structure or artificial dental implants by a newly engineered tooth seems like an exciting prospect, there are obvious practical obstacles still to be overcome before this might be available as a routine clinical treatment [108, 109].

\section{ENGINEERING OF SOFT TISSUES \\ 3.1. Skin and Oral Mucosa}

The most successful application of tissue engineering to date is the development of skin equivalents. In dermatology, the ability to produce large amount of dermal-epidermal tissue from a small portion of the patient's skin in a short amount of time makes it possible to treat a variety of burns and chronic skin wounds [110,111]. In and around the oral cavity, the need for soft tissue restoration/reconstruction is most often related to the lost gingival tissues and less frequently to the lost oral mucosa and skin in cases of disfigured tissues following severe burns, in radical resective surgery to treat invasive cancers, or in oral and maxillofacial traumatic wounds. The main goal of periodontal plastic and cosmetic oral surgery is to restore the aesthetics of the diseased or lost tissues. Many techniques have been developed over the years to restore the aesthetics of gingival and oral tissues. These include pedicle flaps [112-115], epithelialized/nonepithelialized soft tissue autografts [116, 117], or bilaminar techniques [118, 119]. Since they are autologous, the body does not reject these grafts. However, there are several problems associated with autologous grafts/flaps, including donor site morbidity, tissue shortage, and retention of the original characteristics of the donor tissue. Thus, clinicians have been interested in an alternative source for donor tissue.

As in dermatology, tissue engineering is being explored to provide the replacement equivalent for oral tissues. Similar to oral hard tissues, there are various approaches to engineering oral soft tissues (see Fig. 2). 


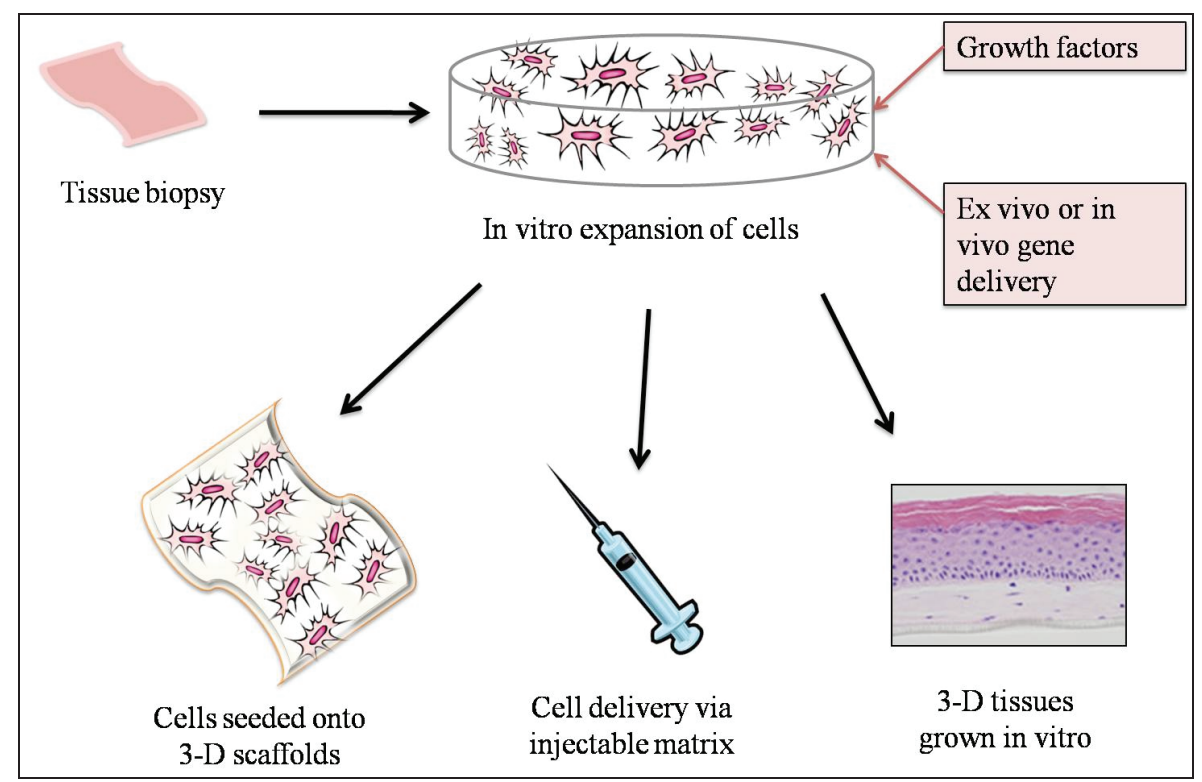

Figure 2. Tissue engineering approaches for oral soft tissues.

The desired cell types can be cultured and expanded ex vivo and injected directly into the soft tissue defect site [120]. They can be seeded onto porous scaffolds (see Fig. 3) with or without the presence of bioactive factors and implanted into the defect area $[121,122]$. Bilayered cell therapy is an example of a living product constructed of type 1 bovine collagen and viable allogeneic human fibroblasts and keratinocytes which produce many growth factors [123]. Another approach can be to grow threedimensional tissues ex vivo $[124,125]$ before being transplanted in vivo.

The dental literature contains many reports on the applications of tissue engineering techniques to biopsy and grow patient's own cells on different scaffold materials, to be used as a substitute for soft tissue autografts. Tissue engineered oral equivalents have been explored for the management of gingival recession [34, 35, 121, 126] (see Fig. 4), inadequate keratinized gingiva [122, 124, 127], interdental papillary loss [120], preprosthetic surgery [128], and in oral and maxillofacial reconstructive surgery [129131]. Unlike engineered skin, tissue-engineered human oral mucosa has not yet been commercialized for clinical applications. However, studies with favorable histological and clinical results have been carried out with tissue-engineered oral mucosal equivalents for intra- and extra-oral treatment, in the pursuit of the best and most predictable method of regenerating the lost soft tissues. 


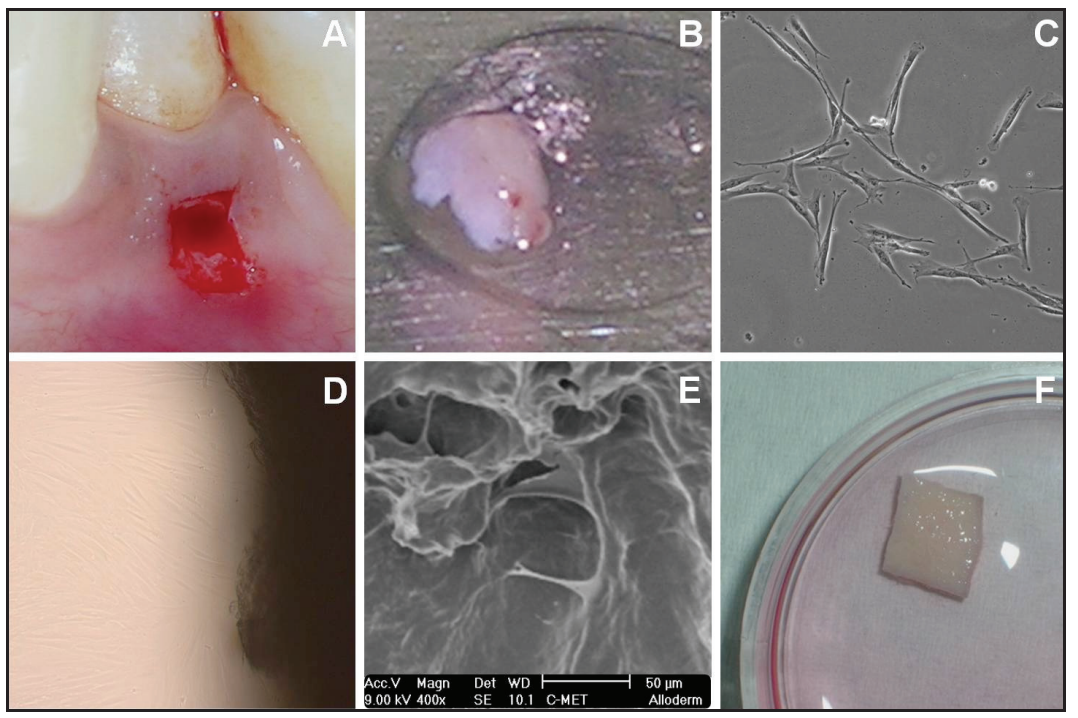

Figure 3. Ex vivo culturing of human gingival fibroblasts. (A) A gingival biopsy (2 $\times 2 \times 1 \mathrm{~mm}$ ) is harvested from the donor site. (B) Biopsied tissue is transported to the laboratory and processed. (C) Primary culture showing a colony of gingival fibroblasts under the phase contrast microscope. (D) Several fibroblasts seen migrating into the acellular dermal matrix allograft scaffold under the phase contrast microscope. (E) Gingival fibroblast seen on the acellular dermal matrix allograft scaffold (scanning electron microscopy, original magnification $\times 400$ ) $(\mathrm{F})$ Acellular dermal matrix scaffold seeded with gingival fibroblasts ready for transplantation.
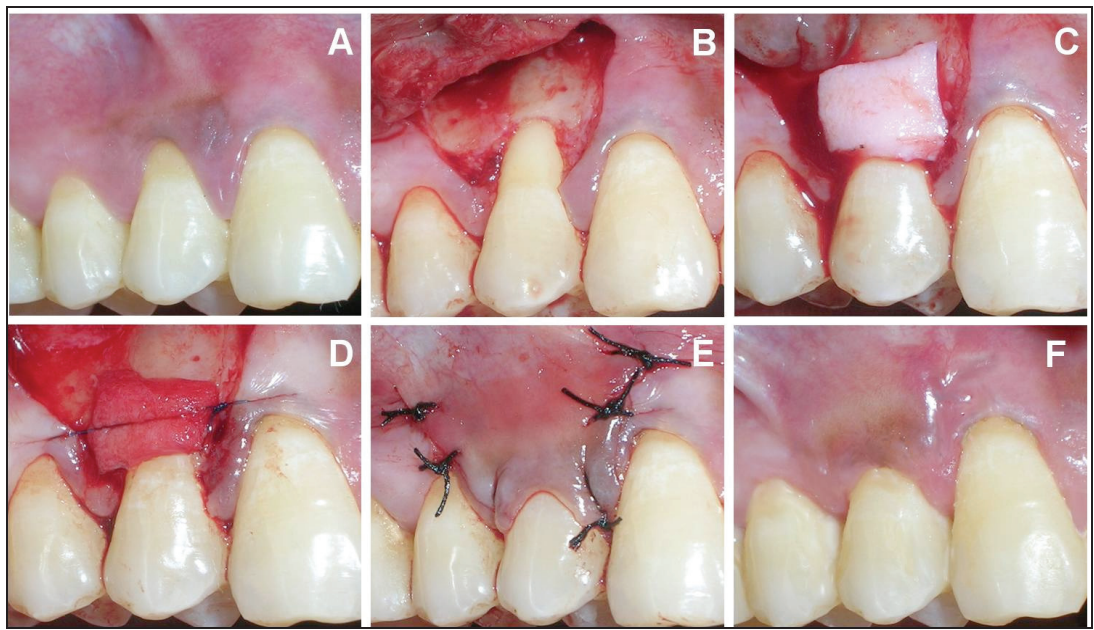

Figure 4. Management of gingival recession by tissue engineering. (A) Preoperative gingival recession. (B) A trapezoidal flap is elevated. (C, D) The ADMA scaffold containing the patient's gingival fibroblasts is positioned and sutured to the recipient site. (E) Flap coronally positioned and sutured. (F) Postoperative view after six months. 


\subsection{Salivary Glands}

The most challenging goal of tissue engineering is replacement of complete organs, and significant progress has been made in efforts to engineer salivary gland function. The production and secretion of saliva is very critical to the maintenance of oral health and function. Salivary glands can be damaged by various developmental or acquired disorders like Sjögren's syndrome, salivary gland neoplasms, infectious or obstructive diseases, and their treatment modalities such as irradiation, resection, etc [132]. Defective salivary gland function, leading to decreased salivary secretion, can result in problems such as dental decay, pain, recurrent mucosal infections, and swallowing difficulties [133]. Tissue engineering technology is being sought to offer treatment alternatives for restoration of both form and function of salivary glands. Baum et al. initiated, via cell transplantation approach, the development of an artificial salivary gland substitute composed of polymer tube lined by epithelial cells [134]. Other approaches used gene therapy to convert existing non-secretory ductal epithelial cells (following irradiation therapy) into secretory cells capable of fluid movement [135, 136]. With many researchers [134-139] working in this area, the prospect for the development of an artificial salivary gland looks promising which could be very effective for treating conditions associated with lost salivary gland function and thus improving the quality of life of the individual.

\section{FUTURE DIRECTIONS/CONSIDERATIONS}

Tissue engineering represents one of the most exciting advances in regenerative medicine. The ability to produce new tissues and organs from the patient's own cells has changed treatments and prognoses for numerous patients. It provides several advantages over traditional methods of treatment. It can provide unlimited source of graft material from a small donor site with minimal discomfort to the patient. However, the fact remains that the in vitro environment, where these tissue engineering constructs are developed, are technically different from the actual environment in the defect site in the body as they lack several systemic controls/components involved in homeostatic regulation in vivo. There are some questions open to speculation regarding what happens when these ex-vivo-developed tissue constructs are placed from the apparently stable culture environment to the more dynamic in vivo environment. Do these ex vivoexpanded tissue cells adapt to the surrounding environment and remain viable through the crucial post-operative healing period? Or do these cells succumb to the biological and systemic influences to which they have not been subjected to in vitro? Is the new tissue formed by the implanted cells per se or by the surrounding induced or preexisting cells?

Further studies are necessary to maximize cell viability, optimize total cell density, optimize the bioactive molecule dose, control its delivery rate and understand the binding kinetics of the biofactors. Studies are required to design scaffolds with chemical compositions, pore sizes, and surface characteristics that allow cells to maintain their optimum tissue-forming potential. The degradation kinetics of polymerbased delivery systems need to be explored to enable control of the release profile of growth factors, in order to achieve optimized concentrations of growth factors, which 
is a primary goal of these systems. Also, one of the most challenging issues is to understand how the various components involved in engineering tissues can be integrated to produce predictable tissue regeneration. More research should also be directed to the issue of how to achieve rapid vascularization of the tissue-engineered constructs to optimize the survival of the tissue-engineered graft. Regeneration of tissues by tissue engineering is an inevitable therapy, and continuing collaborative efforts among research scientists, engineers, funding agencies, and dental professionals are required to pool resources to hasten its development. The unleashed potential of regenerative therapy may benefit millions of patients each year.

\section{CONCLUSION}

Significant progress has already been made in the field of oral surgery with the help of ever-evolving field of tissue engineering. Similar to the past, the next decade promises greater advancements in the field of surgical and healthcare engineering. While this biotechnology is still in its experimental phase in regards to tooth engineering, numerous successful animal and human clinical trials of bone and soft tissue regeneration in the oral and maxillofacial region have been documented. Advances in tissue engineering and stem cell biology have provided a great impetus for the biomedical community to translate these findings into clinical applications. Tissue engineering, with its multipotent building blocks and appropriate molecular and environmental cues, promises successful regenerative surgery without the disadvantages of the conventional approaches.

\section{CONFLICT OF INTEREST: None.}

\section{REFERENCES}

[1] Langer R, Vacanti JP. Tissue engineering. Science 1993; 260:920-926.

[2] Putnam AJ, Mooney DJ. Tissue engineering using synthetic extracellular matrices. Nat Med 1996; 2:824-826.

[3] Fortier LA. Stem cells: Classification, controversies and clinical applications. Vet Surg 2005; 34:415-423.

[4] Bianco P, Riminucci M, Gronthos S, Gehron Robey PG. Bone marrow stromal stem cells: nature, biology and potential applications. Stem Cells 2001; 19:180-192.

[5] Fuchs E, Segre JA. Stem cells: A new lease on life. Cell 2000; 100:143-155.

[6] Blau HM, Brazelton TR, Weimann JM. The evolving concept of a stem cell: Entity or function? Cell 2001; 105:829-841.

[7] Gronthos S, Zannettino AC, Hay SJ, Shi S, Graves SE, Kortesidis A, et al. Molecular and cellular characterization of highly purified stromal stem cells derived from human bone marrow. $J$ Cell Sci 2003; 116:1827-1835.

[8] Bonab MM, Alimoghaddam K, Talebian F, Ghaffari SH, Ghavamzadeh A, Nikbin B. Aging of mesenchymal stem cell in vitro. BMC Cell Biol 2006; 7:14.

[9] Gronthos S, Brahim J, Li W, Fisher LW, Cherman N, Boyde A, et al. Stem cell properties of human dental pulp stem cells. J Dent Res 2002; 81:531-535.

[10] Huang GT, Gronthos S, Shi S. Mesenchymal stem cells derived from dental tissues vs those from other sources: their biology and role in regenerative medicine. J Dent Res 2009; 88(9):792-806. 
[11] Seo B, Miura M, Gronthos S, Bartold PM, Batouli S, Brahim J, et al. Investigation of multipotent postnatal stem cells from human periodontal ligament. Lancet 2004; 364:149-155.

[12] Seo BM, Miura M, Sonoyama W, Coppe C, Stanyon R, Shi S. Recovery of stem cells from cryopreserved periodontal ligament. J Dent Res 2005; 84(10): 907-912.

[13] Bartold PM, Shi S, Gronthos S. Stem cells and periodontal regeneration. Periodontol 2000 2006a; 40:164-172.

[14] Miura M, Gronthos S, Zhao M, Lu B, Fisher LW, Robey PG, et al. SHED: Stem cells from human exfoliated deciduous teeth. Proc Natl Acad Sci USA 2003; 100:5807-5812.

[15] Tomar GB, Srivastava RK, Gupta N, Barhanpurkar AP, Pote ST, Jhaveri HM, et al. Human gingivaderived mesenchymal stem cells are superior to bone marrow-derived mesenchymal stem cells for cell therapy in regenerative medicine. Biochem Biophys Res Commun 2010; 393(3):377-83.

[16] Zhang QZ, Su WR, Shi SH, Wilder-Smith P, Xiang AP, Wong A, et al. Human gingiva-derived mesenchymal stem cells elicit polarization of M2 macrophages and enhance cutaneous wound healing. Stem Cells 2010; 28(10):1856-68.

[17] Mitrano TI, Grob MS, Carrión F, Nova-Lamperti E, Luz PA, Fierro FS, et al. Culture and characterization of mesenchymal stem cells from human gingival tissue. J Periodontol 2010; 81(6):917-925.

[18] Sonoyama W, Liu Y, Fang D, Yamaza T, Seo BM, Zhang C, et al. Mesenchymal stem cell mediated functional tooth regeneration in swine. PLOS ONE 2006; 1(1):e79.

[19] Huang GT, Sonoyama W, Liu Y, Liu H, Wang S, Shi S. The hidden treasure in apical papilla: the potential role in pulp/dentin regeneration and bioroot engineering. $J$ Endod 2008; 34:645-651.

[20] Kim BS, Mooney DJ. Development of biocompatible synthetic extracellular matrices for tissue engineering. Trends Biotechnol 1998; 16:224-30.

[21] Kao RT, Murakami S, Beirne OR. The use of biologic mediators and tissue engineering in dentistry. Periodontol 2000 2009; 50:127-153.

[22] Bartold PM, Xiao Y, Lyngstaadas SP, Paine ML, Snead ML. Principles and applications of cell delivery systems for periodontal regeneration. Periodontol 2000 2006; 41:123-135.

[23] Tabata Y. Tissue regeneration based on growth factor release. Tissue Eng 2003: 9(Suppl. 1):S1-S15.

[24] Boontheekul T, Mooney DJ. Protein based signaling systems in tissue engineering. Curr $O p$ Biotechnol 2003; 14:559-565.

[25] Wang AY, Leong S, Liang Y, Huang R, Chen C, Yu S. Immobilization of growth factors on collagen scaffolds mediated by polyanionic collagen mimetic peptides and its effect on endothelial cell morphogenesis. Biomacromolecules 2008; 9:2929-2936.

[26] Yang S, Leong K-F, Du Z, Chua C-K. The design of scaffolds for use in tissue engineering. Part 1. Traditional factors. Tissue Eng 2001; 7:679-689.

[27] Habers GM, Healy KE. The effect of ligand type and density on osteoblast adhesion, proliferation, and matrix mineralization. J Biomed Mater Res 2005; 15:855-869.

[28] Park J, Lee J, Park Y, Rhee S, Lee S, Kim T, Seol Y, Lee Y, Ku Y, Rhyu I, Han S, Chung C. Enhanced bone regeneration in beagle dogs with bovine bone mineral coated with a synthetic oligopeptide. $J$ Periodontol 2007; 78:2150-2155.

[29] Cochran DL, Wozney JM. Biological mediators for periodontal regeneration. Periodontol 2000 1999; 19:40-58.

[30] Sarment DP, Cooke JW, Miller SE, Jin Q, McGuire MK, Kao RT, et al. Effect of rhPDGF-BB on bone turnover during periodontal repair. J Clin Periodontol 2006; 33(2):135-40.

[31] Howell TH, Fiorellini JP, Paquette DW, Offenbacher S, Giannobile WV, Lynch SE. A phase I/II clinical trial to evaluate a combination of recombinant human platelet-derived growth factor-BB and recombinant human insulin-like growth factor-1 in patients with periodontal disease. J Periodontol 1997; 68:1186-1193. 
[32] Jayakumar A, Rajababu P, Rohini S, Butchibabu K, Naveen A, Reddy PK, et al. Multi-centre, randomized clinical trial on the efficacy and safety of recombinant human platelet-derived growth factor with $\beta$-tricalcium phosphate in human intra-osseous periodontal defects. J Clin Periodontol 2011; 38(2):163-72.

[33] Nevins M, Giannobile WV, McGuire, MK, et.al. Platelet-derived growth factor stimulates bone fill and rate of attachment level gain: Results of a large multi-centre, randomized controlled trial. J Periodontol 2005; 76:2205-2215.

[34] McGuire MK, Scheyer ET. Growth factor mediated treatment of recession defects: A randomized controlled clinical trial and histological and micro-CT examination. J Periodontol 2009; 80:550-564.

[35] McGuire MK, Scheyer ET, Nevins M, Schupbach P. Evaluation of human recession defects treated with coronally advanced flaps and either purified recombinant human platelet-derived growth factor-BB with beta tricalcium phosphate or connective tissue: A histological and micro-CT examination. Int J Perio Rest Dent 2009;29:6-21

[36] Murakami S, Takayama S, Kitamura M, Shimabukuro Y, Yanagi K, Ikezawa K, et al. Recombinant human fibroblast growth factor (bFGF) stimulates periodontal regeneration in class II furcation defects created in beagle dogs. J Periodont Res 2003; 38:97-103.

[37] Yamada Y, Ueda M, Hibi H, Baba S. A novel approach to periodontal tissue regeneration with mesenchymal stem cells and platelet-rich plasma using tissue engineering technology: A clinical case report. Int J Perio Rest Dent 2006; 26(4):363-9.

[38] Yamamiya K, Okuda K, Kawase T, Hata K-I, Wolff LF, Yoshie H. Tissue-engineered cultured periosteum used with platelet-rich plasma and hydroxyapatite in treating human osseous defects. $J$ Periodontol 2008; 79(5):811-818.

[30] Ito K, Yamada Y, Naiki T, Ueda M. Simultaneous implant placement and bone regeneration around dental implants using tissue-engineered bone with fibrin glue, mesenchymal stem cells and plateletrich plasma. Clin Oral Implants Res 2006; 17(5):579-586.

[40] Wikesjo UM, Razi SS, Sigurdsson TJ, Tatakis DN, Lee MB, Ongpipattanakul B, et al. Periodontal repair in dogs: effect of recombinant human transforming growth factor-betal on guided tissue regeneration. J Clin Periodontol 1998; 25:475-481.

[41] Ferrara N, Gerber HP. The role of vascular endothelial growth factor in angiogenesis. Acta Haematol 2001; 106:148-156.

[42] Fowlkes JL, Thrailkill KM, Liu L, Wahl EC, Bunn RC, Cockrell GE, et al. Effects of systemic and local administration of recombinant human IGF-I (rhIGF-I) on de novo bone formation in an aged mouse model. J Bone Miner Res 2006; 21(9):1359-66.

[43] Barboza E, Cau' la AL, Cau' la F, Oliveira de Souza R, Neto LG, Sorensen RG, et al. Effect of recombinant human bone morphogenetic protein-2 in an absorbable collagen sponge with spaceproviding biomaterials on the augmentation of chronic alveolar ridge defects. J Periodontol 2004; 75:702-708.

[44] Jung RE, Glauser R, Scharer P, Hammerle CH, Sailer HF, Weber FE. Effect of rhBMP-2 on guided bone regeneration in humans. Clin Oral Implants Res 2003; 14:556-568.

[45] Kim SJ, Shun HS, Shin SW. Effect of bone block graft with rhBMP-2 on vertical bone augmentation. Int J Oral Maxillofac Surg 2010; 39(9):883-8.

[46] Wikesjö UME, Sorensen RG, Wozney JM. Augmentation of alveolar bone and dental implant osseointegration: clinical implications of studies with rhBMP-2. A comprehensive review. $J$ Bone Joint Surg Am 2001; 83:S136-S145.

[47] Roldan JC, Jepsen S, Schmidt C, Knuppel H, Rueger DC, Acil Y, et al. Sinus floor augmentation with simultaneous placement of dental implants in the presence of platelet-rich plasma or recombinant human bone morphogenetic protein-7. Clin Oral Implants Res 2004; 15:716-723.

[48] Boyne PJ, Lilly LC, Marx RE, Moy PK, Nevins M, Spagnoli DB, et al. De novo bone induction by recombinant human bone morphogenetic protein-2 (rhBMP-2) in maxillary sinus floor augmentation. J Oral Maxillofac Surg 2005; 63:1693-1707. 
[49] Boyne PJ, Marx RE, Nevins M, Triplett G, Lazaro E, Lilly LC, et al. A feasibility study evaluating rhBMP-2/absorbable collagen sponge for maxillary sinus floor augmentation. Int $J$ Periodontics Restorative Dent 1997; 17:11-25.

[50] Sigurdsson TJ, Nguyen S, Wikesjö UME. Alveolar ridge augmentation with rhBMP-2 and bone to implant contact in induced bone. Int J Periodontics Restorative Dent 2001; 21:461-473.

[51] Sykaras N, Triplett RG, Nunn ME, Iacopino AM, Opperman LA. Effect of recombinant human bone morphogenetic protein-2 on bone regeneration and osseointegration of dental implants. Clin Oral Implants Res 2001; 12:339-349.

[52] Wikesjö UME, Qahash M, Thomson RC, Cook AD, Rohrer MD, Wozney JM, et al. RhBMP-2 significantly enhances guided bone regeneration. Clin Oral Implants Res 2004; 15:194-204.

[53] Selvig KA, Sorensen RG, Wozney JM, Wikesjö UME. Bone repair following recombinant human bone morphogenetic protein-2 stimulated periodontal regeneration. J Periodontol 2002; 73:1020-1029.

[54] Wikesjö UME, Sorensen RG, Kinoshita A, Jian Li X, Wozney JM. Periodontal repair in dogs: effect of recombinant human bone morphogenetic protein-12 (rhBMP-12) on regeneration of alveolar bone and periodontal attachment. J Clin Periodontol 2004; 31:662-670.

[55] Heijl L, Heden G, Svardstrom G, Ostgren A. Enamel matrix derivative (EMDOGAIN) in the treatment of intrabony periodontal defects. J Clin Periodontol 1997; 24:705-714.

[56] Yukna RA, Mellonig JT. Histologic evaluation of periodontal healing in humans following regenerative therapy with enamel matrix derivative. J Periodontol 2000; 71:752-759.

[57] Sculean A, Chiantella GF, Windisch P, Keglevich T, Gera I. Clinical and histologic evaluation of human intrabony defects treated with an enamel matrix derivative (Emdogain). Int $J$ Periodontics Restorative Dent 2000; 20:374-381.

[58] Hagewald S, Pischon N, Jawor P, Bernimoulin JP, Zimmermann B. Effects of enamel matrix derivative on proliferation and differentiation of primary osteoblasts. Oral Surg Oral Med Oral Pathol Oral Radiol Endod 2004; 98:243-249.

[59] Pischon N, Zimmermann B, Bernimoulin JP, Hagewald S. Effects of an enamel matrix derivative on human osteoblasts and PDL cells grown in organoid cultures. Oral Surg Oral Med Oral Pathol Oral Radiol Endod 2006; 102:551-557.

[60] Basmanav FB, Kose GT, Hasirci V. Sequential growth factor delivery from complexed microspheres for bone tissue engineering. Biomaterials 2008; 29:4195-4204.

[61] Kempen DH, Kruyt MC, Lu L, Wilson CE, Florschutz AV, Creemers LB, et al. Effect of autologous bone marrow stromal cells seeding and bone morphogenetic protein-2 delivery on ectopic bone formation in a microspheres/poly(propylene fumarate) composite. Tissue Eng Part A 2008; 15:587-594.

[62] James J, Steijn-Myagkaya GL. Death of osteocytes. Electron microscopy after in vitro ischaemia. $J$ Bone Joint Surg Br 1986; 68:620-624.

[63] Bouhadir KH, Mooney DJ. Promoting angiogenesis in engineered tissues. J Drug Target 2001; 9:397-406.

[64] Pelissier P, Villars F, Mathoulin-Pelissier S, Bareille R, Lafage-Proust MH, Vilamitjana-Amedee J. Influences of vascularization and osteogenic cells on heterotopic bone formation within a madreporic ceramic in rats. Plast Reconstr Surg 2003; 111:1932-1941.

[65] Hofmann A, Ritz U, Verrier S, Eglin D, Alini M, Fuchs S, et al. The effect of human osteoblasts on proliferation and neo-vessel formation of human umbilical vein endothelial cells in a long-term $3 \mathrm{D}$ coculture on polyurethane scaffolds. Biomaterials 2008; 29:4217-4226.

[66] Warnke PH, Springer IN, Wiltfang J, Acil Y, Eufinger H, et al. Growth and transplantation of a custom vascularised bone graft in a man. Lancet 2004; 364:766-770.

[67] Meijer GJ, de Bruijn JD, Koole R, van Blitterswijk CA Cell-based bone tissue engineering. PLoS Med 2007; 4(2):e9.

[68] Damien CJ, Parsons JR. Bone graft and bone graft substitutes: A review of current technology and applications. J Appl Biomater 1991; 2:187-208. 
[69] Urist MR. Bone: Formation by autoinduction. Science 1965; 150:893-899.

[70] Arrington ED, Smith WJ, Chambers HG, Bucknell AL, Davino NA. Complications of iliac crest bone graft harvesting. Clin Orthop Relat Res 1996; 329:300-309.

[71] Strong DM, Friedlaender GE, Tomford WW, Springfield DS, Shives TC, Burchardt H, et al. Immunologic responses in human recipients of osseous and osteochondral allografts. Clin Orthop Relat Res 1996; 326:107-114.

[72] Sogal A, Tofe AJ. Risk assessment of bovine spongiform encephalopathy transmission through bone graft material derived from bovine bone used for dental applications. J Periodontol 1999; 70:1053-1063.

[73] Reynolds MA, Aichelmann-Reidy ME, Branch-Mays GL, Gunsolley JC. The efficacy of bone replacement grafts in the treatment of periodontal osseous defects. A systematic review. Ann Periodontol 2003; 8:227-265.

[74] Kawaguchi H, Hirachi A, Hasegawa N, Iwata T, Hamaguchi H, Shiba H, et al. Enhancement of periodontal tissue regeneration by transplantation of bone marrow mesenchymal stem cells. $J$ Periodontol 2004; 75(9):1281-1287.

[75] Ribeiro FV, Suaid FF, Ruiz KGS, Salmon CR, Paparotto T, Nociti FH Jr, et al. Periosteum-derived cells as an alternative to bone marrow cells for bone tissue engineering around dental implants. A histomorphometric study in beagle dogs. J Periodontol 2010; 81(6):907-916.

[76] Schimming R, Schmelzeisen R. Tissue-engineered bone for maxillary sinus augmentation. J Oral Maxillofac Surg 2004; 62(6):724-729.

[77] Beaumont C, Schmidt RJ, Tatakis DN, Zafiropoulos G-G. Use of engineered bone for sinus augmentation. J Periodontol 2008; 79(3):541-548.

[78] Yamada Y, Nakamura S, Ito K, Kohgo T, Hibi H, Nagasaka, Ueda M. Injectable tissue-engineered bone using autogenous bone marrow-derived stromal cells for maxillary sinus augmentation: clinical application report from a 2-6 year follow-up. Tissue Engineering (Part A) 2008; 14(10):1699-1707.

[79] McAllister BS, Haghighat K, Gonshor A. Histologic evaluation of a stem cell-based sinusaugmentation procedure. J Periodontol 2009; 80(4):679-686.

[80] Abukawa H, Shin M, Williams WB, Vacanti JP, Kaban LB, Troulis MJ, et al. Reconstruction of mandibular defects with autologous tissue-engineered bone. J Oral Maxillofac Surg 2004; 62(5):601-606.

[81] Chen F, Feng X, Wu W, Ouyang H, Gao Z, Cheng X, et al. Segmental bone tissue engineering by seeding osteoblast precursor cells into titanium mesh-coral composite scaffolds. Int J Oral Max Surg 2007; 36(9):822-827.

[82] Alhadlaq A, Mao JJ. Tissue-engineered neogenesis of human-shaped mandibular condyle from rat mesenchymal stem cells. J Dent Res 2003; 82:951-956.

[83] Alhadlaq A, Mao JJ. Tissue engineered osteochondral constructs in the shape of an articular condyle. J Bone Joint Surg Am 2005; 87:936-944.

[84] Abukawa H, Terai H, Hannouche D, Vacanti JP, Kaban LB, Troulis MJ, et al. Formation of a mandibular condyle in vitro by tissue engineering. J Oral Max Surg 2003; 61(1):94-100.

[85] Canalis E. Regulation of bone remodeling. In: Favus MJ, ed. Primer on the metabolic bone diseases and disorders of mineral metabolism. Lippincott-Raven: Philadelphia, 1996; 29-34.

[86] Giannobile WV. Periodontal tissue engineering by growth factors. Bone 1996; 19:23S-37S.

[87] Geesink RG, Hoefnagels NH, Bulstra SK. Osteogenic activity of OP-1 bone morphogenetic protein (BMP-7) in a human fibular defect. J Bone Joint Surg Br 1999; 81:710-718.

[88] Baum BJ, Kok M, Tran SD, Yamano S. The impact of gene therapy on dentistry: a revisiting after six years. J Am Dent Assoc 2002; 133:35-44.

[89] Shea LD, Smiley E, Bonadio J, Mooney DJ. DNA delivery from polymer matrices for tissue engineering. Nat Biotechnol 1999; 17:551-554.

[90] Fang J, Zhu YY, Smiley E, Bonadio J, Rouleau JP, Goldstein SA, et al. Stimulation of new bone formation by direct transfer of osteogenic plasmid genes. Proc Natl Acad Sci USA 1996; 93:5753-5758. 
[91] Zhu Z, Lee CS, Tejeda KM, Giannobile WV. Gene transfer and expression of platelet-derived growth factors modulate periodontal cellular activity. J Dent Res 2001; 80:892-897.

[92] Chen QP, Giannobile WV. Adenoviral gene transfer of PDGF downregulates gas gene product PDGFalphaR and prolongs ERK and Akt/PKB activation. Am J Physiol Cell Physiol 2002; 282:C538-C544.

[93] Jin Q, Anusaksathien O, Webb SA, Printz MA, Giannobile WV. Engineering of tooth-supporting structures by delivery of PDGF gene therapy vectors. Mol Ther 2004; 9:519-526.

[94] Franceschi RT, Wang D, Krebsbach PH, Rutherford RB. Gene therapy for bone formation: in vitro and in vivo osteogenic activity of an adenovirus expressing BMP7. J Cell Biochem 2000; 78:476-86.

[95] Krebsbach PH, Gu K, Franceschi RT, Rutherford RB. Gene therapy-directed osteogenesis: BMP-7transduced human fibroblasts form bone in vivo. Hum Gene Ther 2000; 11:1201-10.

[96] Herring SW, Ochareon P. Bone-special problems of the craniofacial region. Orthod Craniofac Res 2005; 8:174-182.

[97] Giesen EB, Ding M, Dalstra M, Van Eijden TM. Changed morphology and mechanical properties of cancellous bone in the mandibular condyles of edentate people. J Dent Res 2004; 83:255-259.

[98] Fischbach C, Mooney DJ. Polymers for pro- and anti-angiogenic therapy. Biomaterials 2007; 28:2069-2076.

[99] Mitragotri S, Lahann J. Physical approaches to biomaterial design. Nat. Mater. 2009; 8:15-23.

[100] Shi S, Bartold P, Miura M, Seo B, Robey P, Gronthos S. The efficacy of mesenchymal stem cells to regenerate and repair dental structures. Orthod Craniofac Res 2005, 8:191-199.

[101] Rutherford RB. BMP-7 gene transfer to inflamed ferret dental pulps. Eur J Oral Sci 2001; 109:422-424

[102] Mooney DJ, Powell C, Piana J, Rutherford B. Engineering dental pulp-like tissue in vitro. Biotechnol Prog 1996; 12:865-868.

[103] Buurma B, Gu K, Rutherford RB. Transplantation of human pulpal and gingival fibroblasts attached to synthetic scaffolds. Eur J Oral Sci 1999; 107:282-289.

[104] Prescott RS, Alsanea R, Fayad MI, Johnson BR, Wenckus CS, Hao J, et al. In vivo generation of dental pulp-like tissue by using dental pulp stem cells, a collagen scaffold, dentin matrix protein 1 after subcutaneous transplantation in mice. J Endod 2008; 34:421-426.

[105] Esposito M, Hirsh JM, Lekholm U, Thompsen P. Biological factors contributing to failures of osseointegrated oral implants. European J of Oral Sciences 1998; 106:527-51.

[106] Sharpe PT, Young CS. Test-tube teeth. Sci Am 2005; 293:34-41.

[107] Duailibi M, Duailibi S, Young C, Bartlett J, Yelick PC. Bioengineered teeth from cultured rat tooth bud cells. J Dent Res 2004; 83:523-528.

[108] Ohazama A, Modino SAC, Miletich I, Sharpe PT. Stem-cell-based tissue engineering of murine teeth. J Dent Res 2004; 83:518-522.

[109] Yen A, Sharpe P. Stem cells and tooth tissue engineering. Cell Tissue Res 2008; 331:359-372.

[110] Naughton G, Mansbridge J, Gentzkow G. A metabolically active human dermal replacement for treatment of diabetic foot ulcers. Artif Organs 1997; 21:1203-1210.

[111] Hansbrough J. Current status of skin replacements for coverage of extensive burn wounds. J Trauma 1990; 30:155-162.

[112] Grupe HE, Warren RF. Repair of gingival defects by a sliding flap operation. J Periodontol 1956; 27:92.

[113] Bernimoulin JP, Luscher B, Mühlemann HR. Coronally repositioned periodontal flap. Clinical evaluation after one year. J Clin Periodontol 1975; 2:1-13.

[114] Egyedi P. Utilization of the buccal fat pad for closure of oro-antral and/or oro-nasal communications. J Maxillofac Surg 1977; 5:241-244. 
[115] Ducic Y, Burye M. Nasolabial flap reconstruction of oral cavity defects: A report of 18 cases. J Oral Maxillofac Surg 2000; 58:1104-1108.

[116] Sullivan HC, Atkins JH. Free autogenous gingival grafts. III. Utilization of grafts in the treatment of gingival recession. Periodontics 1968; 6:152-160.

[117] Langer B, Langer L. Subepithelial connective tissue graft technique for root coverage. J Periodontol $1985 ; 56: 715-720$

[118] Raetzke PB. Covering localized areas of root exposure employing the "envelope" technique. $J$ Periodontol 1985; 56:397-402.

[119] Harris RJ. The connective tissue and partial thickness double pedicle graft: A predictable method of obtaining root coverage. J Periodontol 1992; 63:477-486.

[120] McGuire MK, Scheyer ET. A randomized, double-blind, placebo-controlled study to determine the safety and efficacy of cultured and expanded autologous fibroblast injections for the treatment of interdental papillary insufficiency associated with the papilla priming procedure. J Periodontol 2007; 78(1):4-17.

[121] Jhaveri HM, Chavan MS, Tomar GB, Deshmukh VL, Wani MR, Miller PD. Acellular dermal matrix seeded with autologous gingival fibroblasts for the treatment of gingival recession-a proof of concept study. J Periodontol 2010; 81(4):616-625.

[122] Pini Prato G, Rotundo R, Magnani C, Soranzo C, Muzzi L, Cairo F. An autologous cell hyaluronic acid graft technique for gingival augmentation: A case series. J Periodontol 2003; 74(2):262-267.

[123] McGuire MK, Scheyer ET, Nunn ME, Levin PT. A pilot study to evaluate a tissue engineered bilayered cell therapy as an alternative to tissue from the palate. $J$ Periodontol 2008; 79:1847-1856.

[124] Mohammadi M, Shokrgozar MA, Mofid R. Culture of human gingival fibroblasts on a biodegradable scaffold and evaluation of its effect on attached gingiva: a randomized, controlled pilot study. $J$ Periodontol 2007; 78(10):1897-1903.

[125] Izumi K, Tackacs G, Terashi H, Feinberg. Ex vivo development of a composite human oral mucosal equivalent. J Oral Maxillofac Surg 1999; 57(5):571-77.

[126] Wilson TA, McGuire MK, Nunn ME. Evaluation of the safety and efficacy of periodontal applications of a living tissue-engineered human fibroblast-derived dermal substitute. II. Comparison to the subepithelial connective tissue graft: A randomized controlled feasibility study. J Periodontol 2005; 76:881-889.

[127] McGuire MK, Nunn ME. Evaluation of the safety and efficacy of periodontal applications of a living tissue-engineered human fibroblast-derived dermal substitute. I. Comparison to the gingival autograft: A randomized controlled pilot study. J Periodontol 2005; 76:867-880.

[128] Sauerbier S, Gutwald R, Wiedmann-Al-Ahmad M, Lauer G, Schmelzeisen R. Clinical application of tissue-engineered transplants. Part I: mucosa. Clin Oral Implants Res 2006; 17(6):625-632.

[129] Izumi K, Feinberg SE, Iida A, Yoshizawa M. Intraoral grafting of an ex vivo produced oral mucosa equivalent: a preliminary report. Int J Oral Maxillofac Surg 2003; 32(2):188-197.

[130] Lauer G, Schimming R. Tissue-engineered mucosa graft for reconstruction of the intraoral lining after freeing of the tongue: A clinical and immunohistologic study. J Oral Maxillofac Surg 2001; 59(2):169175 .

[131] Moharamzadeh K, Brook IM, Van Noort R, Scutt AM, Thornhill MH. Tissue-engineered oral mucosa: A review of the scientific literature. J Dent Res 2007; 86(2):115-124.

[132] McEwen DR, Sanchez MM. A guide to salivary gland disorders. AORN J 1997; 65(3):554-556, 559567; quiz 568-559, 571-552.

[133] Fox PC. Acquired salivary dysfunction. Drugs and radiation. Ann N Y Acad Sci 1998; 842:132-137.

[134] Baum BJ, Wang S, Cukierman E, Delporte C, Kagami H, Marmary Y, et al. Re-engineering the functions of a terminally differentiated epithelial cell in vivo. Ann N Y Acad Sci 1999; 875:294-300.

[135] Baum BJ, O'Connell BC. In vivo gene transfer to salivary glands. Crit Rev Oral Biol Med 1999; 10:276-83. 
[136] Delporte C, O'Connell BC, He X, Lancaster HE, O'Connell AC, Agre P, et al. Increased fluid secretion following adenovirus mediated transfer of the aquaporin-1 cDNA irradiated rat salivary glands. Proc Natl Acad Sci USA 1997; 94:3268-73.

[137] Bücheler M, Wirz C, Schütz A, Bootz F. Tissue engineering of human salivary gland organoids. Acta Otolaryngol 2002; 122(5):541-5.

[138] Joraku A, Sullivan CA, Yoo JJ, Atala A. Tissue engineering of functional salivary gland tissue. Laryngoscope 2005; 115(2):244-8.

[139] Joraku A, Sullivan CA, Yoo JJ, Atala A. In-vitro reconstitution of three-dimensional human salivary gland tissue structures. Differentiation 2007; 75(4):318-24. 


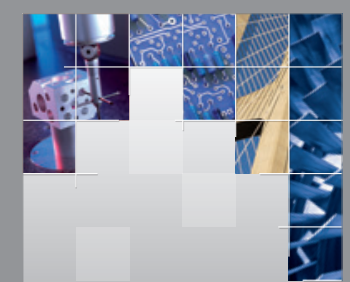

\section{Enfincering}
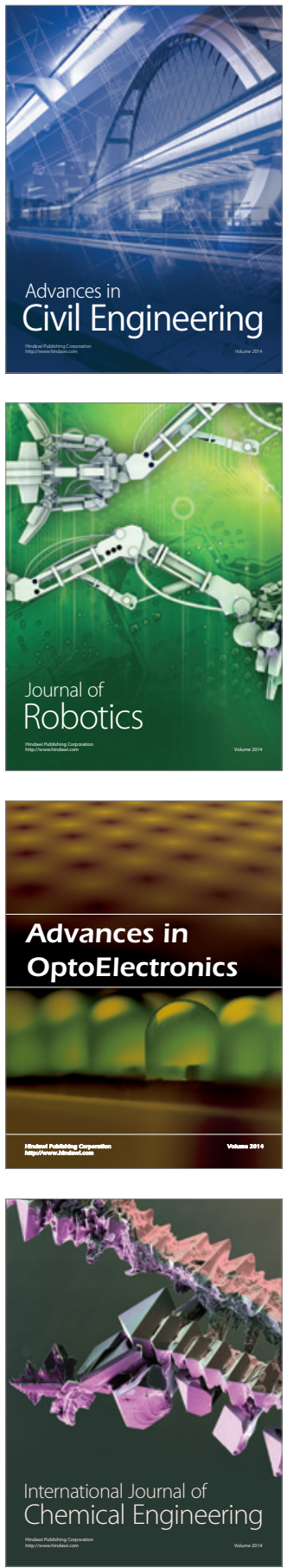

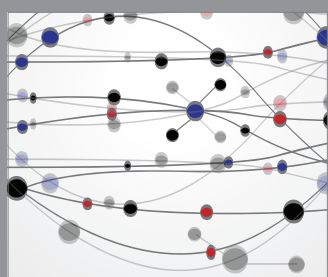

The Scientific World Journal

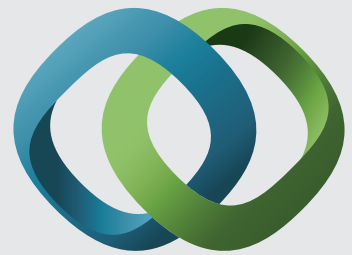

\section{Hindawi}

Submit your manuscripts at

http://www.hindawi.com
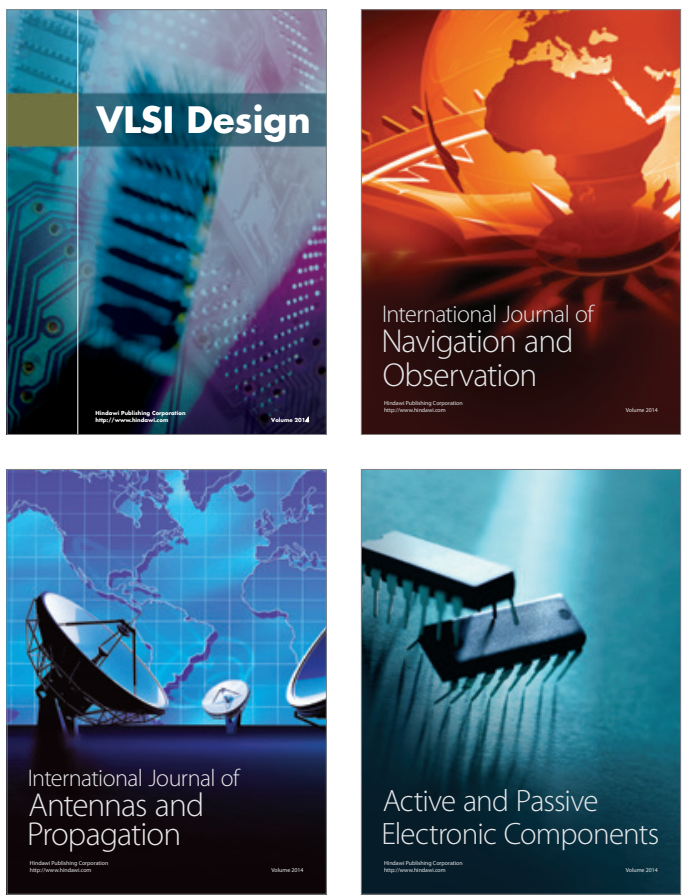
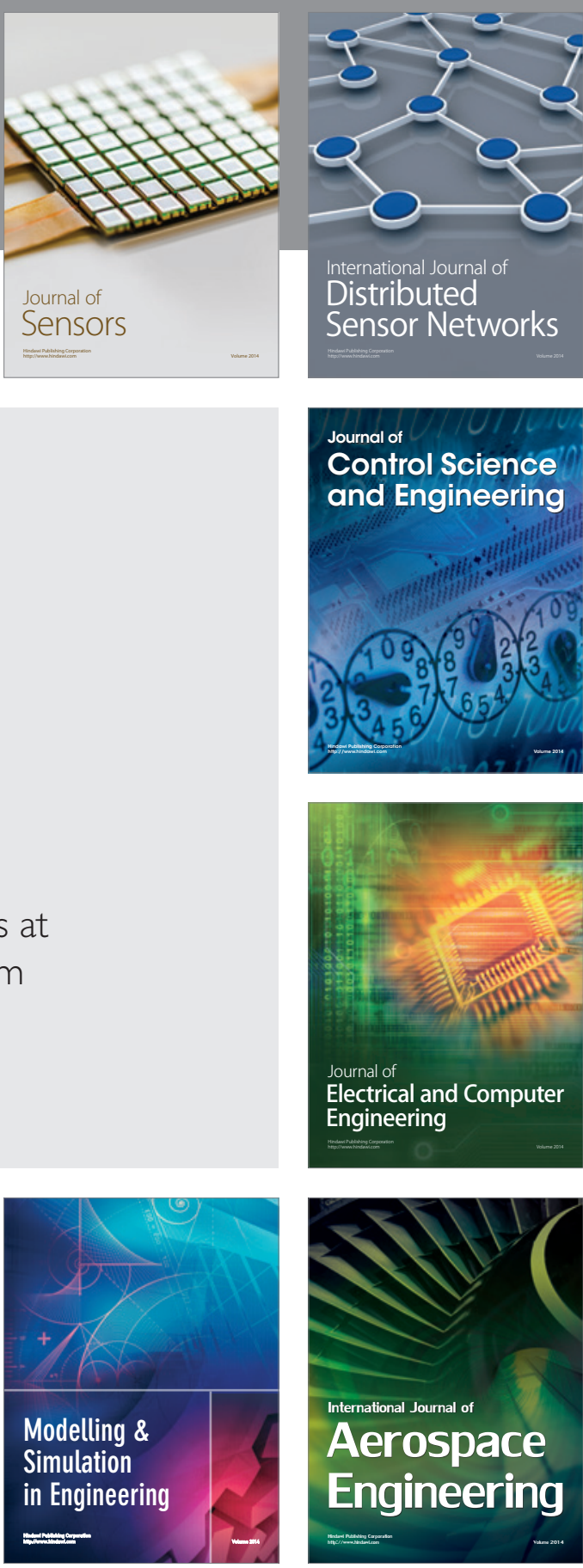

International Journal of

Distributed

Sensor Networks

Journal of

Control Science

and Engineering
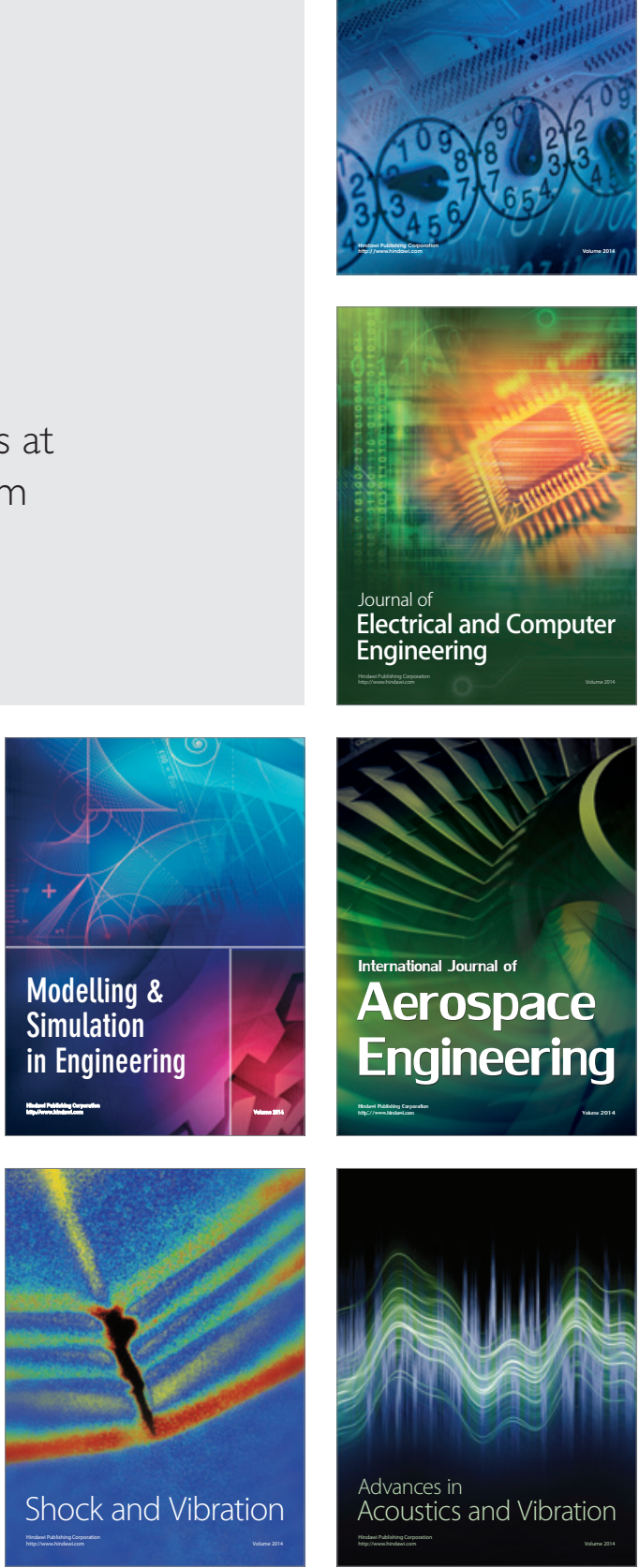